\title{
Correction to: Employment and Wages of Immigrants and Descendants of Immigrants: Measures of Inequality and Perceived Discrimination
}

\author{
Dominique Meurs
}

\section{Correction to: \\ C. Beauchemin et al. (eds.), Trajectories and Origins: Survey on the Diversity of the French Population, INED Population Studies 8, https://doi.org/10.1007/978-3-319-76638-6_4}

The Chapter was published without the following citation. The same has now been included in the chapter.

A larger analysis of wage inequalities, including a study of differences by origin in working hours and commuting time as well as intergenerational job mobility, was published in: Meurs D., Lhommeau B., Okba M., 2015, Emplois, salaires et mobilité intergénérationnelle (chapter 8), in: Beauchemin C., Hamel C., Simon P. (ed.), Trajectoires et origines : enquête sur la diversité des populations en France, Paris, Ined (collection Grandes Enquêtes), p. 233-262. Other results regarding access to employment and discrimination are available in: Brinbaum Y., Meurs D., Primon J.-L., 2015, Situation sur le marché du travail: statut d'activité, accès à l'emploi et discrimination (chapter 7), in: Beauchemin C., Hamel C., Simon P. (ed.), Trajectoires et origines : enquête sur la diversité des populations en France, Paris, Ined (collection Grandes Enquêtes), p. 203-232.

The updated version of this chapter can be found at https://doi.org/10.1007/978-3-319-76638-6_4 